\title{
Comparison Among Sweet Corn Heterotic Patterns
}

\author{
P. Revilla ${ }^{1}$, V.M. Rodríguez, R.A. Malvar, A. Butrón, and A. Ordás \\ Misión Biológica de Galicia, CSIC, Apartado 28, 36080 Pontevedra, Spain
}

AdDitional INDEX WORDS. maize, Zea mays, heterosis, adaptation

\begin{abstract}
Four sweet corn (Zea mays L.) heterotic patterns have been reported among sugary1 (su1) open-pollinated cultivars: two among sweet corn cultivars ('Golden Bantam' $x$ 'Country Gentleman' and 'Golden Bantam' $x$ 'Stowell's Evergreen'), one related to the 'Reid' $x$ 'Lancaster' field corn heterotic pattern ('NE-HY-13A' $x$ 'NE-HY-13B'), and one related to the northern $x$ southern Spain field corn heterotic pattern ('EPS31' $x$ 'EPS32'). The objective of this research was to compare the performance of sweet corn heterotic patterns. The four crosses and their seven parents were evaluated in 2 years, at two environments in northwestern Spain, as well as in a cold chamber. 'Golden Bantam' x 'Stowell's Evergreen' and 'Golden Bantam' x 'Country Gentleman' had poorer agronomic performance and better ear quality than 'NE-HY-13A' $x$ 'NE-HY-13B' and 'EPS31' $x$ 'EPS32'. 'Golden Bantam' $x$ 'Stowell's Evergreen' had the best cold tolerance in the cold chamber. Earliness, emergence, and early vigor were higher for 'EPS31' $x$ 'EPS32', related to the northern $x$ southern Spain field corn heterotic pattern. Heterosis was positive and significant for several traits for 'Golden Bantam' $x$ 'Stowell's Evergreen' and 'Golden Bantam' x 'Country Gentleman,' while heterosis was not significant for 'NE-HY-13A' $x$ 'NE-HY-13B' and 'EPS31' $x$ 'EPS32'. The objective of capitalizing on the 'Reid' $x$ 'Lancaster' and the northern $x$ southern Spain field corn heterotic patterns for improving sweet corn has failed. We believe that heterosis is lost when field corn heterotic patterns are combined with sweet corn, due to incompatibility in gene combination among sweet and field corn genetic backgrounds.
\end{abstract}

Most sweet corn inbreds are related to three sugaryl (sul)openpollinated cultivars: 'Golden Bantam', 'Stowell's Evergreen', and 'Country Gentleman', 'Golden Bantam' being involved in most inbreds' pedigrees (Tracy, 2001). A few investigators have tried to establish heterotic patterns in sul sweet corn, either by defining heterotic relationships among sweet corn cultivars (Revilla and Tracy, 1997), or by crossing sweet corn cultivars to cultivars representing field corn heterotic patterns (Davis et al., 1988; Revilla et al., 2000b). Heterotic patterns have not been defined for other sweet corn mutants, where variability is narrower than for sul germplasm.

Based on previous studies, Revilla and Tracy (1997) investigated the heterotic patterns among six open-pollinated sweet corn cultivars representing the relevant variability within su1 germplasm. These authors reported two heterotic patterns among sweet corn cultivars: 1) 'Country Gentleman'x 'Golden Bantam', 'Pease Crosby', and 'Lindsey Meyer Blue'; and 2) 'Stowell's Evergreen'x 'Golden Bantam', 'Pease Crosby', and 'Lindsey Meyer Blue'. Midparent heterosis was $80 \%$ for 'Country Gentleman' $x$ 'Golden Bantam' and 42\% for 'Stowell's Evergreen' $x$ 'Golden Bantam'. In that study, midparent heterosis was high mainly due to the poor performance of the parents in late planting.

Davis et al. (1988) capitalized on the 'Reid Yellow Dent' $x$ 'Lancaster Sure Crop' field corn heterotic pattern for sweet corn, by crossing field corn inbred lines from each type to sweet corn inbred lines and releasing the 'NE-HY-13A'x 'NE-HY-13B' sweet corn heterotic pattern. Similarly, Revilla et al. (2000b) used the northern $\mathrm{x}$ southern Spanish field corn heterotic pattern defined by Ordás (1991) to produce a sweet corn heterotic pattern, by

Received for publication 23 Aug. 2005. Accepted for publication 15 Dec. 2005. Research supported by the Committee for Science and Technology of Spain (Project Cod. AGL2004-06776), the Autonomous Government of Galicia, Spain (PGIDIT04RAG403006PR) and Excma. Diputación Provincial de Pontevedra, Spain. Misión Biológica de Galicia, Spanish Council for Scientific Research, Apartado 28, 36080 Pontevedra, Spain. V.M. Rodríguez acknowledges a fellowship from the Spanish Ministry of Education and Science.

${ }^{1}$ Corresponding author. Phone: 34986 854800; fax: 34986 841362; e-mail previlla@mbg.cesga.es crossing the field corn synthetic EPS13, from northern Spain, to the sweet corn cultivar Golden Bantam and the field corn synthetic EPS14, from southern Spain, to the sweet corn cultivar Stowell's Evergreen. The sweet $x$ field corn crosses were made plant to plant and, after one generation of recombination, the sweet corn grains were separated from each cross and recombined twice, in order to reduce linkage disequilibrium. The sweet corn cultivars coming from 'EPS13 x Golden Bantam' and 'EPS14 x Stowell's Evergreen' were called 'EPS31' and 'EPS32', respectively.

Breeding sweet corn for the European Atlantic coast, as for other regions with cold springs and short growing seasons, faces some problems with germination and early development (Ordás et al., 1994). The limiting factors for those regions are seedling emergence and early vigor that is normally low for sweet corn (Hotchkiss et al., 1997; Revilla et al., 2003). These authors have evaluated the available sweet corn cultivars for cold tolerance (Hotchkiss et al., 1997) and the heterotic patterns identified among them (Revilla et al., 2003). 'Country Gentleman' and 'Stowell's Evergreen' were among the most sensitive to cold temperatures, both per se and in hybrid combinations, and 'Golden Bantam' was similar to them. Therefore, one of the keys for a potential value of the new heterotic patterns would be their superior germination and early vigor inherited from the field corn heterotic patterns they were developed from.

The objective of this research was to compare the performance of sul sweet corn heterotic patterns 'Country Gentleman' $x$ 'Golden Bantam', 'Stowell's Evergreen' $x$ 'Golden Bantam', 'NE-HY-13A' $x$ 'NE-HY-13B', and EPS13 x 'EPS32'.

\section{Materials and Methods}

Plant material. The $11 \mathrm{sul}$ sweet corn cultivars included in this experiment were the crosses 'NE-HY-13A' $x$ 'NE-HY-13B' (Davis et al., 1988), 'Golden Bantam' x 'Country Gentleman' and 'Golden Bantam'x ‘Stowell's Evergreen' (Revilla and Tracy, 1997), and 'EPS31'x 'EPS32' (Revilla et al., 2000b), plus the parents of the crosses. 'Golden Bantam'(PI255976) was provided by the North Central Regional Plant Introduction Station, Ames, 
Iowa; 'Country Gentleman' and 'Stowell's Evergreen' by Cornell Univ., Ithaca, N.Y.; 'NE-HY-13A' and 'NE-HY-13B' come from the Univ. of Minnesota, Minneapolis; and 'EPS31' and 'EPS32' were obtained at the Misión Biológica de Galicia (Spanish Council for Scientific Research), Pontevedra, Spain.

The cultivar crosses were produced by crossing $\approx 50$ plants from either parent as males to 50 different females from the other parent of the heterotic pattern. Crosses were made plant to plant, and each plant was used solely as male or female. The crosses were recombined at least twice before being included in this study. Recombinations were made by crossing around 50 plants from each cultivars' cross as males to 50 different females. All seed used in these trials was produced in Pontevedra, Spain, in 2002.

FiELD TRIALs. Trials, consisting on randomized complete-block designs with three replications, were sown at two locations in northwestern Spain: Pontevedra (lat. $42^{\circ} 24^{\prime} \mathrm{N}$, long. $8^{\circ} 38^{\prime} \mathrm{W}, 20$ $\mathrm{m}$ above sea level) and Pontecaldelas (lat. $42^{\circ} 23^{\prime} \mathrm{N}$, long. $8^{\circ} 32^{\prime} \mathrm{W}$, $300 \mathrm{~m}$ above sea level) in 2003 and 2004. Both locations have a humid climate with annual rainfall of $\approx 1600 \mathrm{~mm}$. Each two-row experimental plot consisted of 29 hills per row with two kernels per hill. Rows were spaced $0.80 \mathrm{~m}$ apart and hills $0.21 \mathrm{~m}$. Hills were thinned to one plant to achieve a final plant density of $\approx 60,000$ plants/ha.

Traits recorded during plant development were emergence (using a scale where 1 = few plant emerged, 5 = average, and 9 $=$ most plants emerged $)$, early vigor $(1=$ weak, $5=$ average, and 9 = vigorous), pollen shedding (days from sowing to half of the plants showing anthers), silking (days from sowing to half of the plants showing silks), plant height (centimeters from the soil to the tassel top), and ear height (centimeters from the soil to the bearing node of the uppermost ear). When the ears were at eating stage, the traits recorded were number of ears per plant, husks appearance $(1=$ not marketable, $5=$ average, and $9=$ excellent appearance), silk channel ( $1=$ short, $5=$ average, and $9=$ long), silk color $(1=$ dark, $5=$ average, and $9=$ transparent $)$, grain color ( $1=$ diffuse, $5=$ average, and $9=$ intense $)$, tip filling $(1=$ ear tip without grains, $5=$ average, and $9=$ ear tip with full grains), ear appearance $(1=$ not marketable, $5=$ average, and $9=$ excellent appearance $)$, and flavor $(1=$ disagreeable, $5=$ average, and $9=$ agreeable). For all subjective scales, 5 refers to the average appearance of commercial cultivars; qualifications below 5 were assigned for those ears or parts of the ears that did not meet the commercial standards, while the values above 5 mean better appearance than the commercial hybrids. In particular, husks are considered marketable when they cover the ear compactly, have a neat green color and flag leaves; and ears are classified as marketable when they have a cylindrical shape with conical tip, appropriate and proportionate length and diameter, and straight rows. At harvest, the traits recorded were root lodging (percent of plants leaning more than $45^{\circ}$ ), stem lodging (percentage of plants with the stem broken below the main ear), kernel rows, ear length (centimeters), grain yield (megagrams per hectare adjusted at $140 \mathrm{~g} \cdot \mathrm{kg}^{-1}$ moisture content), and grain moisture (grams per kilogram). Harvest was made at dry grain stage instead of at the normal eating stage, following Revilla and Tracy (1997) and Revilla et al. (2000b), to estimate more closely physiological efficiency and to reduce the coefficient of variation for yield and heterosis calculations.

COLD CHAMBER TRIALS. The crosses and cultivars were planted in trays filled with sterilized peat in a cold chamber. Water supply was enough to keep the peat humid. The cold chamber has three shelves at different heights, providing maize light requirements to guarantee normal plant development on each shelf. The trial was set according to a randomized complete-block design with three replications; each replication in one shelf. Each experimental unit consisted of two rows spaced $4 \mathrm{~cm}$ with 13 kernels per row. Sowing depth was $2 \mathrm{~cm}$ and the distance between consecutive kernels was $2 \mathrm{~cm}$ as well. Conditions were set at $10 \mathrm{~h}$ without light at $8{ }^{\circ} \mathrm{C}$ and $14 \mathrm{~h}$ with light at $14^{\circ} \mathrm{C}$.

In the cold chamber we measured percent emergence, days from planting to $50 \%$ emergence (number of days after planting at which at least $50 \%$ of the plants had emerged in a two-row plot $)$, percent survival of emerged plants, vigor $(1=$ weak, $5=$ average, $9=$ vigorous $)$, and color $(1=$ white, $5=$ average, $9=$ dark green). Besides, emergence score was calculated using the formula (Smith and Millet, 1964):

$100 \times \Sigma$ (number of plants emerged at time i/time from planting) Time from planting to end of emergence

Where time is recorded in days and i varied from 9 to $36 \mathrm{~d}$ for this study.

Statistical ANALYSES. Individual analyses of variance were performed for all traits for each environment, as well as for the cold chamber. The sources of variation were replications and cultivars. For the field corn trials, the combined-across-environments analyses of variance included, as sources of variation, environments (each location-year combination), replications within environments, cultivars, and the appropriate interactions. Environments and replications were considered random effects, while cultivars were fixed effects. Mean comparisons among cultivars were performed by using the Fisher's protected LSD $(P$ $=0.05)$. The GLM procedure of SAS was used for all analyses (version 8; SAS Institute, Cary, N.C.). Midparent heterosis was calculated for each cultivar cross. The error term for testing significance of heterosis estimations was calculated from the appropriate mean square, as well as the LSD for comparisons among heterosis, following Keeratinijakal and Lamkey (1993).

\section{Results and Discussion}

FiELd TRIALS. The sweet corn cultivar Country Gentleman had the least emergence, though differences with 'Stowell's Evergreen' were not significant. Emergence of all other cultivars did not differ significantly from those with greatest emergence ('Golden Bantam', 'EPS31', and 'Golden Bantam' x 'Stowell's Evergreen') (Table 1). The cultivars EPS31, EPS32, and EPS31 $x$ EPS32 were the most vigorous cultivars, while 'Stowell's Evergreen' and 'Country Gentleman' had the lowest vigor. 'EPS31' $x$ 'EPS32,' 'EPS31', 'EPS32', and 'Golden Bantam'were the earliest maturing cultivars, while 'Country Gentleman' and 'Stowell's Evergreen' were the latest maturing cultivars.

The synthetic 'EPS31' comes from the combination between the sweet corn cultivar Golden Bantam and the field corn synthetic EPS13, while 'EPS32' comes from the combination between 'Stowell's Evergreen' and EPS14. We intended to capitalize on the quality of the heterotic pattern 'Golden Bantam' $x$ 'Stowell's Evergreen' and the vigor and adaptation of northern $x$ southern Spanish field corn. These results show that the new sweet corn heterotic pattern 'EPS31' $x$ 'EPS32' actually has high vigor and early flowering, as expected. Therefore, the heterotic pattern northern $x$ southern Spain has improved early vigor and early flowering when combined with 'Golden Bantam' $x$ 'Stowell's Evergreen'. The heterotic pattern 'EPS31' $x$ 'EPS32' had the shortest plants, among the cultivar crosses, and lower ears than 
Table 1. Means across environments for 12 agronomic traits of sweet corn, recorded in the field 2 years at two locations in northwestern Spain and in a cold chamber.

\begin{tabular}{|c|c|c|c|c|c|c|c|c|c|c|c|c|}
\hline \multirow[b]{2}{*}{ Accession } & \multicolumn{9}{|c|}{ Field trials } & \multicolumn{3}{|c|}{ Cold chamber trial } \\
\hline & $\begin{array}{l}\text { Emergence } \\
(1-9 \text { scale })^{z}\end{array}$ & $\begin{array}{c}\text { Early } \\
\text { vigor } \\
(1-9 \text { scale })\end{array}$ & $\begin{array}{l}\text { Pollen } \\
\text { shedding } \\
\text { (d) }\end{array}$ & $\begin{array}{l}\text { Silking } \\
\text { (d) }\end{array}$ & $\begin{array}{c}\text { Plant } \\
\text { ht } \\
(\mathrm{cm})\end{array}$ & $\begin{array}{c}\text { Ear } \\
\text { ht } \\
(\mathrm{cm})\end{array}$ & $\begin{array}{c}\text { Root } \\
\text { lodging } \\
(\%)\end{array}$ & $\begin{array}{c}\text { Grain } \\
\text { yield } \\
\left(\mathrm{Mg} \cdot \mathrm{ha}^{-1}\right)\end{array}$ & $\begin{array}{c}\text { Grain } \\
\text { moisture } \\
\left(\mathrm{g} \cdot \mathrm{kg}^{-1}\right)\end{array}$ & $\begin{array}{l}\text { Emergence } \\
\text { rate/day } \\
\text { (plants/d) }\end{array}$ & $\begin{array}{c}\text { Emergence } \\
\text { proportion } \\
(\%)\end{array}$ & $\begin{array}{c}\text { Vigor } \\
\text { (1-9 scale })\end{array}$ \\
\hline Golden Bantam (GB) & $7.8 \mathrm{a}^{\mathrm{y}}$ & $6.0 \mathrm{~b}$ & $62 \mathrm{e}$ & $64 \mathrm{e}$ & $167 \mathrm{e}$ & $49 \mathrm{~d}$ & $14.0 \mathrm{a}$ & $1.98 \mathrm{de}$ & $296 \mathrm{~d}-\mathrm{f}$ & $10.7 \mathrm{bc}$ & $76 a-c$ & $4.5 \mathrm{bc}$ \\
\hline Stowell's Evergreen (SE) & $6.5 \mathrm{bc}$ & $4.5 \mathrm{~cd}$ & $70 \mathrm{~b}$ & $72 \mathrm{ab}$ & $211 \mathrm{~b}$ & $77 \mathrm{ab}$ & $3.0 \mathrm{~b}$ & $1.82 \mathrm{de}$ & $333 \mathrm{a}$ & $5.9 \mathrm{c}$ & $42 \mathrm{~d}$ & $5.0 \mathrm{a}-\mathrm{c}$ \\
\hline Country Gentleman (CG) & $5.3 \mathrm{c}$ & $3.8 \mathrm{~d}$ & $72 \mathrm{a}$ & $73 \mathrm{a}$ & $193 \mathrm{~cd}$ & $59 \mathrm{~cd}$ & $3.3 \mathrm{~b}$ & $1.51 \mathrm{e}$ & $293 \mathrm{ef}$ & $8.4 \mathrm{bc}$ & $49 \mathrm{~cd}$ & $4.0 \mathrm{c}$ \\
\hline $\mathrm{GB} \times \mathrm{SE}$ & $7.8 \mathrm{a}$ & $6.2 \mathrm{~b}$ & $65 \mathrm{~d}$ & $67 \mathrm{~d}$ & $211 b$ & $69 \mathrm{bc}$ & $5.5 \mathrm{~b}$ & $3.22 \mathrm{a}-\mathrm{c}$ & $303 \mathrm{~b}-\mathrm{f}$ & $11.5 \mathrm{a}-\mathrm{c}$ & $82 \mathrm{a}$ & $4.5 \mathrm{bc}$ \\
\hline $\mathrm{GB} \times \mathrm{CG}$ & $7.0 \mathrm{ab}$ & $5.8 \mathrm{bc}$ & $65 \mathrm{~d}$ & $66 \mathrm{~d}$ & $205 \mathrm{bc}$ & $66 \mathrm{bc}$ & $3.5 \mathrm{~b}$ & $2.64 \mathrm{~cd}$ & $309 \mathrm{a}-\mathrm{e}$ & $17.1 \mathrm{a}$ & $85 \mathrm{a}$ & $6.0 \mathrm{a}$ \\
\hline NE-HY-13A (NEA) & $7.5 \mathrm{ab}$ & $5.8 \mathrm{bc}$ & $69 c$ & $70 \mathrm{c}$ & $227 \mathrm{a}$ & $76 a b$ & $5.9 \mathrm{~b}$ & $3.92 \mathrm{a}$ & $333 \mathrm{a}$ & $6.1 \mathrm{c}$ & $45 \mathrm{~d}$ & $5.5 \mathrm{ab}$ \\
\hline NE-HY-13B (NEB) & $7.7 \mathrm{ab}$ & $6.2 \mathrm{~b}$ & $69 c$ & $71 \mathrm{bc}$ & $232 \mathrm{a}$ & $85 \mathrm{a}$ & $4.3 \mathrm{~b}$ & $3.79 \mathrm{ab}$ & $331 \mathrm{ab}$ & $10.6 \mathrm{ab}$ & $78 \mathrm{ab}$ & $6.0 \mathrm{a}$ \\
\hline NEA $\times$ NEB & $7.3 \mathrm{ab}$ & $5.5 \mathrm{bc}$ & $68 \mathrm{c}$ & $70 \mathrm{c}$ & $217 \mathrm{ab}$ & $76 \mathrm{ab}$ & $1.7 \mathrm{~b}$ & $3.74 \mathrm{ab}$ & $324 a-c$ & $9.7 \mathrm{bc}$ & $54 \mathrm{~b}-\mathrm{d}$ & $5.0 \mathrm{a}-\mathrm{c}$ \\
\hline EPS31 & $7.8 \mathrm{a}$ & $6.7 \mathrm{ab}$ & $62 \mathrm{e}$ & $63 \mathrm{e}$ & $193 \mathrm{~cd}$ & $61 \mathrm{c}$ & $3.5 \mathrm{~b}$ & $2.72 \mathrm{~cd}$ & $276 \mathrm{f}$ & $7.9 \mathrm{bc}$ & $60 \mathrm{a}-\mathrm{d}$ & $5.5 \mathrm{ab}$ \\
\hline EPS32 & $7.5 \mathrm{ab}$ & $6.5 \mathrm{ab}$ & $62 \mathrm{e}$ & $64 \mathrm{e}$ & $187 \mathrm{~d}$ & $61 \mathrm{c}$ & $2.6 \mathrm{~b}$ & $2.43 \mathrm{~cd}$ & $323 a-d$ & $8.5 \mathrm{bc}$ & $53 \mathrm{~b}-\mathrm{d}$ & $5.5 \mathrm{ab}$ \\
\hline EPS31 x EPS32 & $7.7 \mathrm{ab}$ & $7.8 \mathrm{a}$ & $62 \mathrm{e}$ & $63 \mathrm{e}$ & $189 \mathrm{~d}$ & $61 \mathrm{c}$ & $2.4 \mathrm{~b}$ & $2.92 \mathrm{bc}$ & $301 \mathrm{c}-\mathrm{f}$ & $9.5 \mathrm{bc}$ & $64 \mathrm{a}-\mathrm{d}$ & $6.0 \mathrm{a}$ \\
\hline Mean & 7.3 & 5.9 & 66 & 67 & 203 & 67 & 4.5 & 2.80 & 311 & 9.9 & 62 & 5.2 \\
\hline $\operatorname{LSD}(P=0.05)$ & 1.3 & 1.5 & 1.2 & 1.4 & 14.9 & 11.2 & 6.1 & 0.91 & 28 & 6.1 & 23 & 1.1 \\
\hline
\end{tabular}

$\mathrm{z} 1=$ the poorest value, $5=$ the average value, $9=$ the most favorable value.

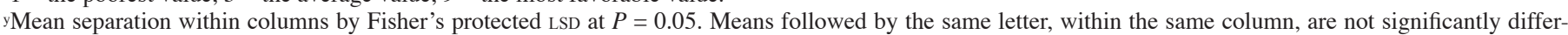
ent.

'NE-HY-13A'x 'NE-HY-13B.' 'Golden Bantam' had more lodging than any other cultivar.

'Golden Bantam', 'Country Gentleman', and 'Stowell's Evergreen' had the lowest yield, and, among the cultivar crosses, 'NE-HY-13A' $x$ 'NE-HY-13B' was the highest yielder, but did not differ from 'EPS31'x 'EPS32' and 'Golden Bantam'x 'Stowell's Evergreen'. Regarding grain moisture, the cultivar $\times$ environment interaction was very important and the differences among heterotic patterns were not significant in the combined analysis as in most environments (data not shown). However, grain moisture will not be further considered because of its implications on sugar content, growing cycle and environment on sweet corn.

The agronomic performance of the heterotic patterns was most favorable for 'EPS31' $x$ 'EPS32' because it was among the superior cultivars for emergence, early vigor, and flowering dates and did not differ from the highest yielder (Table 1). The cultivar cross 'Golden Bantam' x 'Country Gentleman' had the poorest agronomic performance.

'Golden Bantam'x 'Stowell's Evergreen', 'Golden Bantam'x 'Country Gentleman', and 'EPS31' had the most attractive husk appearance (Table 2). 'EPS31'x 'EPS32' and 'Country Gentleman' had the shortest silk channel, but differences were not significant among the remaining cultivars. Although silk color is a qualitative trait, it was not consistent over environments, due to quantitative variation in color intensity. Ear appearance was poorer for the sweet corn cultivars than for other cultivars or crosses, and differences among cultivar crosses were not significant. 'Golden Bantam' and 'Golden Bantam' x 'Stowell's Evergreen' had the best flavor. None of the cultivar crosses involving field corn had a flavor similar to 'Golden Bantam' x 'Stowell's Evergreen'. Loss of quality in 'NE-HY-13A', 'NE-HY-13B', 'EPS31', and 'EPS32' respect to the sweet corn cultivars was probably due to the high proportion of field corn genes, $50 \%$ at least, given that half of the original cultivars were field corn and some natural and artificial selection can be expected across the production of the new sweet corn cultivars.

Apart from 'Country Gentleman', that had the largest number of kernel rows due to the irregular row pattern of this cultivar (Tracy, 2001), none of the cultivar crosses had a large number of rows. 'NE-HY-13A' x 'NE-HY-13B' and 'Golden Bantam' x
'Country Gentleman' had more kernel rows than 'Golden Bantam'x 'Stowell's Evergreen' and 'EPS31'x 'EPS32'. Differences among cultivar crosses were not significant for ear length and the cultivar $\times$ environment interaction was very important. However, the sweet corn cultivars Golden Bantam, Country Gentleman, and Stowell's Evergreen had the shortest ears on average and in the individual environments.

The ear quality was highest for 'Golden Bantam' x 'Stowell's Evergreen', because it has the highest rating for flavor and was among those with the highest rating for husk and ear appearance, silk channel and ear length (Table 2). On the contrary, 'EPS31' $x$ 'EPS32' had the poorest ear quality overall, and 'NE-HY-13A' $x$ 'NE-HY-13B' had the worst flavor.

Davis et al. (1988) reported that 'NE-HY-13A' and 'NE-HY13B' were similar in appearance, comparable to field corn in vigor, ear diameter and length, and presented large variability for most quality traits. The poorer performance found in these trials could be due to some selection for adaptation to the growing conditions of northwestern Spain, where springs are cooler and wetter and growing cycles shorter than the upper midwestern United States.

COLD Chamber trial. Differences among cultivars were significant for emergence rate and proportion and for early vigor and were not significant for days to emergence, survival proportion and color (data not shown). Emergence rate was larger for 'Golden Bantam' x 'Country Gentleman' and 'Golden Bantam' $x$ 'Stowell's Evergreen', though the last one did not significantly differ from 'NE-HY-13A'x 'NE-HY-13B' and 'EPS31'x 'EPS32' (Table 1). 'Golden Bantam' $\mathrm{x}$ 'Stowell's Evergreen' was not significantly different from 'Stowell's Evergreen,' which had the lowest emergence rate.

Emergence proportion ranged from $85 \%$ for 'Golden Bantam' x 'Country Gentleman' to $42 \%$ for 'Stowell's Evergreen.' The cultivar crosses 'Golden Bantam' x 'Country Gentleman' and 'Golden Bantam' x 'Stowell's Evergreen' had also the largest emergence proportion, and 'EPS31' $x$ 'EPS32' was not significantly different from them. 'NE-HY-13A' $x$ 'NE-HY-13B' had lower emergence proportion than the first ones. The most vigorous accessions were 'EPS31'x 'EPS32', 'NE-HY-13B', and 'Golden Bantam' x 'Country Gentleman'. 
Table 2. Means across environments for seven ear traits of sweet corn recorded in the field 2 years at two locations in northwestern Spain.

\begin{tabular}{|c|c|c|c|c|c|c|c|}
\hline Accessions & $\begin{array}{c}\text { Husks } \\
\text { appearance } \\
(1-9 \text { scale })^{z}\end{array}$ & $\begin{array}{c}\text { Silk } \\
\text { channel } \\
(1-9 \text { scale })\end{array}$ & $\begin{array}{c}\text { Silk } \\
\text { color } \\
(1-9 \text { scale })\end{array}$ & $\begin{array}{c}\text { Ear } \\
\text { appearance } \\
(1-9 \text { scale })\end{array}$ & $\begin{array}{c}\text { Flavor } \\
\text { (1-9 scale) }\end{array}$ & $\begin{array}{c}\text { Kernel } \\
\text { rows } \\
\text { (no.) }\end{array}$ & $\begin{array}{c}\text { Ear } \\
\text { length } \\
(\mathrm{cm})\end{array}$ \\
\hline Golden Bantam (GB) & $4.4 \mathrm{~cd}^{y}$ & $6.7 \mathrm{a}$ & $4.8 \mathrm{bc}$ & $3.9 \mathrm{~b}-\mathrm{d}$ & $4.5 \mathrm{ab}$ & $10 \mathrm{~g}$ & $13.6 \mathrm{e}$ \\
\hline Stowell's Evergreen (SE) & $4.0 \mathrm{~d}$ & $6.3 \mathrm{a}$ & $6.2 \mathrm{ab}$ & $3.6 \mathrm{~cd}$ & $2.7 \mathrm{de}$ & $16 \mathrm{~b}$ & $14.3 \mathrm{de}$ \\
\hline Country Gentleman (CG) & $3.0 \mathrm{e}$ & $3.6 \mathrm{c}$ & $6.6 \mathrm{a}$ & $3.2 \mathrm{~d}$ & $2.0 \mathrm{f}$ & $18 \mathrm{a}$ & $14.3 \mathrm{c}-\mathrm{e}$ \\
\hline GB $\times$ SE & $5.9 \mathrm{a}$ & $6.3 \mathrm{a}$ & $4.8 \mathrm{bc}$ & $5.2 \mathrm{a}$ & $5.1 \mathrm{a}$ & $13 \mathrm{e}$ & $15.7 \mathrm{a}-\mathrm{c}$ \\
\hline $\mathrm{GB} \times \mathrm{CG}$ & $5.6 \mathrm{ab}$ & $6.1 \mathrm{a}$ & $4.1 \mathrm{c}$ & $4.3 \mathrm{a}-\mathrm{c}$ & $4.1 \mathrm{~b}$ & $14 \mathrm{~d}$ & $15.4 \mathrm{a}-\mathrm{d}$ \\
\hline NE-HY-13A (NEA) & $4.7 \mathrm{~b}-\mathrm{d}$ & $6.6 \mathrm{a}$ & $7.3 \mathrm{a}$ & $5.2 \mathrm{a}$ & $3.3 \mathrm{cb}$ & $14 \mathrm{~cd}$ & $16.2 \mathrm{ab}$ \\
\hline NE-HY-13B (NEB) & $4.5 \mathrm{~cd}$ & $6.3 \mathrm{a}$ & $7.3 \mathrm{a}$ & $5.1 \mathrm{a}$ & $2.4 \mathrm{ef}$ & $15 \mathrm{bc}$ & $16.6 \mathrm{a}$ \\
\hline NEA x NEB & $4.5 \mathrm{~cd}$ & $6.3 \mathrm{a}$ & $6.8 \mathrm{a}$ & $4.3 \mathrm{a}-\mathrm{c}$ & $2.6 \mathrm{~d}-\mathrm{f}$ & $14 \mathrm{~cd}$ & $16.2 \mathrm{ab}$ \\
\hline EPS31 & $5.0 \mathrm{ab}$ & $5.8 \mathrm{ab}$ & $6.9 \mathrm{a}$ & $4.7 \mathrm{ab}$ & $4.0 \mathrm{bc}$ & $11 \mathrm{f}$ & $15.4 \mathrm{a}-\mathrm{d}$ \\
\hline EPS32 & $4.6 \mathrm{~cd}$ & $5.5 \mathrm{ab}$ & $7.3 \mathrm{a}$ & $4.3 \mathrm{acd}$ & $4.1 \mathrm{~b}$ & 12 ef & $15.0 \mathrm{~b}-\mathrm{d}$ \\
\hline EPS31 x EPS32 & $4.5 \mathrm{~cd}$ & $4.6 \mathrm{bc}$ & $6.8 \mathrm{a}$ & $4.4 \mathrm{a}-\mathrm{c}$ & $3.8 \mathrm{bc}$ & $12 \mathrm{e}$ & $15.3 \mathrm{a}-\mathrm{d}$ \\
\hline Mean & 4.6 & 5.8 & 6.2 & 4.4 & 3.5 & 13 & 15.3 \\
\hline $\operatorname{LSD}(P=0.05)$ & 1.0 & 1.3 & 1.6 & 0.9 & 0.7 & 1.0 & 1.4 \\
\hline
\end{tabular}

$\mathrm{z} 1=$ the poorest value, $5=$ the average value, $9=$ the most favorable value.

yMean separation within columns by Fisher's protected $1 \mathrm{sd}$ at $P=0.05$. Means followed by the same letter, within the same column, are not significantly different.

Therefore, 'Golden Bantam' x 'Country Gentleman' was the most cold tolerant heterotic pattern in controlled environment, and the use of field corn to improve the sweet corn heterotic patterns has not been successful to improve the cold tolerance of sweet corn heterotic patterns.

Heterosis. Midparent heterosis across environments was significant for nine traits in the field trials (Table 3 ) and three traits in the cold chamber. In the field, 'Golden Bantam' x 'Stowell's Evergreen' had desirable significant heterosis for pollen shedding, plant height, husk and ear appearance, flavor, ear length, and yield, and in the cold chamber, for emergence proportion. 'Golden Bantam' x 'Country Gentleman' had favorable significant heterosis for all traits except ear appearance in the field and emergence rate in the cold chamber. 'NE-HY-13A' $x$ 'NE-HY$13 \mathrm{~B}$ ' had favorable significant heterosis only for pollen shedding, in the field, and negative significant heterosis for early vigor in the cold chamber. Heterosis was not significant for 'EPS31' $x$ 'EPS32' for any of the traits.

Revilla and Tracy (1997) found average midparent heterosis of $29 \%$ in an early planting, and $57 \%$ in a late planting for grain yield among sweet corn cultivars, and hypothesized that the difference was due to the worst performance of the parents in the late planting. These authors reported heterosis of $45 \%$ and $115 \%$ for 'Golden Bantam' $x$ 'Stowell's Evergreen' in the first and second planting, respectively, and 34 and 49\%, respectively for 'Golden Bantam' x 'Country Gentleman.' Midparent heterosis was calculated from dry grain yield in both the publication of Revilla and Tracy (1997) and the present paper. In the present trials, midparent heterosis was high for 'Golden Bantam' x 'Stowell's Evergreen' and for 'Golden Bantam' x 'Country Gentleman', presumably due to the lack of adaptation of these sweet corn cultivars to northwestern Spain (Ordás et al., 1994). Ordás (1991) found an average midparent heterosis for grain yield of $20 \%$ among field corn synthetics. Significant midparent heterosis was observed among EPS13 and EPS14 (Vales et al., 2001) that were the base for producing 'EPS31' and 'EPS32' when crossed to 'Golden Bantam' and 'Stowell's Evergreen,' respectively. Those field $x$ sweet corn combinations were proposed by Revilla et al. (2000b) and Velasco et al. (2002) based on heterosis among sweet corn, field corn and sweet $\mathrm{x}$ field corn cultivars, trying to capitalize the heterosis from field and sweet corn heterotic patterns previously defined by Ordás (1991) and Revilla and Tracy (1997), respectively.

The evaluation in the cold chamber of the sweet corn diallel reported by Revilla et al. (2003) did not find significant differences among cultivars for emergence proportion, while it did for days to emergence, and shoot and root weight. Heterosis for 'Golden Bantam' x 'Stowell's Evergreen' for these three traits was not significant or negative, while for 'Golden Bantam' $x$ 'Country Gentleman' heterosis was positive. These results confirm that 'Country Gentleman' performed poorly, and that 'Golden Bantam' x 'Country Gentleman' had positive heterosis under cold conditions.

Midparent heterosis was significant for grain yield only for the cultivar crosses 'Golden Bantam' $x$ 'Stowell's Evergreen' and 'Golden Bantam' x 'Country Gentleman', while heterosis was not significant for crosses among 'EPS31' and 'EPS32' or among 'NE-HY-13A' and 'NE-HY-13A'. A possible explanation is that the sweet corn cultivars Golden Bantam, Stowell's Evergreen, and Country Gentleman were poorly adapted and, therefore, performed worse than their hybrids, while 'EPS31', 'EPS32', 'NE-HY-13A', and 'NE-HY-13A' had a better performance, comparable to their respective crosses.

Failure to capitalize on the 'Reid' $x$ 'Lancaster' (Davis et al., 1988), or the northern $x$ southern Spain heterotic pattern (Revilla et al., 2000b) for sweet corn could be attributed to incompatibility in gene combination when sweet corn genes are incorporated to a field corn genetic background. Reduced viability or even lethality of sugaryl in field corn backgrounds has been reported by several authors (Martins and Da Silva, 1998; Revilla et al., 2000a; Tracy, 2001).

\section{Conclusion}

The sweet corn heterotic patterns 'Golden Bantam'x 'Stowell's Evergreen' and 'Golden Bantam'x 'Country Gentleman' (Revilla and Tracy, 1997), had poorer agronomic performance though 'Golden Bantam' $x$ 'Stowell's Evergreen' had better cold tolerance than the heterotic patterns 'NE-HY-13A' $x$ 'NE-HY-13B' and 'EPS31' $x$ 'EPS32', coming from field corn heterotic patterns 
Table 3. Midparent heterosis $\left(\mathrm{H}^{2}\right)$ of four sweet corn cultivar crosses evaluated in the field 2 years at two locations in northwestern Spain and in a cold chamber.

\begin{tabular}{|c|c|c|c|c|c|}
\hline \multirow[b]{2}{*}{ Trait } & \multicolumn{4}{|c|}{ Sweet corn heterotic patterns } & \multirow[b]{2}{*}{$\begin{array}{c}\text { LSD } \\
(P=0.05)\end{array}$} \\
\hline & $\begin{array}{c}\text { Golden Bantam X } \\
\text { Stowell's Evergreen }\end{array}$ & $\begin{array}{c}\text { Golden Bantam X } \\
\text { Country Gentleman }\end{array}$ & $\begin{array}{c}\text { NE-HY-13A X } \\
\text { NE-HY-13B }\end{array}$ & $\begin{array}{l}\text { EPS31x } \\
\text { EPS32 }\end{array}$ & \\
\hline & \multicolumn{5}{|c|}{ Field trials } \\
\hline Pollen shedding (d) & $-1^{z} a b^{y}$ & $-2^{z} b$ & $-1^{\mathrm{z}} \mathrm{ab}$ & $0 \mathrm{a}$ & 1 \\
\hline Silking (d) & $-1 \mathrm{a}$ & $-2.5^{\mathrm{z}} \mathrm{b}$ & $-0.5 \mathrm{a}$ & $-0.5 \mathrm{a}$ & 1.7 \\
\hline Plant height $(\mathrm{cm})$ & $22^{z} \mathrm{a}$ & $25^{\mathrm{z}} \mathrm{a}$ & $-12.5 \mathrm{~b}$ & $-1 \mathrm{~b}$ & 14 \\
\hline Ear height $(\mathrm{cm})$ & $6 a b$ & $12^{\mathrm{z}} \mathrm{a}$ & $-4.5 b$ & $0 \mathrm{ab}$ & 14 \\
\hline Husk appearance $(1-9 \text { scale })^{x}$ & $1.7 \mathrm{z} a$ & $1.9 \mathrm{z} \mathrm{a}$ & $-0.1 \mathrm{~b}$ & $-0.3 \mathrm{~b}$ & 1.2 \\
\hline Ear appearance (1-9 scale) & $1.45^{\mathrm{z}} \mathrm{a}$ & $0.75 \mathrm{ab}$ & $-0.85 \mathrm{c}$ & $-0.1 \mathrm{bc}$ & 1.13 \\
\hline Flavor (1-9 scale) & $1.5^{\mathrm{z}} \mathrm{a}$ & $0.85^{\mathrm{z}} \mathrm{a}$ & $-0.25 b$ & $-0.25 \mathrm{~b}$ & 0.88 \\
\hline Ear length $(\mathrm{cm})$ & $1.75^{\mathrm{z}} \mathrm{a}$ & $1.45^{\mathrm{z}} \mathrm{a}$ & $-0.2 \mathrm{~b}$ & $0.1 \mathrm{ab}$ & 1.71 \\
\hline \multirow[t]{2}{*}{ Yield $\left(\mathrm{Mg} \cdot \mathrm{ha}^{-1}\right)$} & $1.32^{\mathrm{z}} \mathrm{a}$ & $0.89^{\mathrm{z}} \mathrm{ab}$ & $-0.12 b$ & $0.35 \mathrm{ab}$ & 1.12 \\
\hline & \multicolumn{5}{|c|}{ Cold chamber trial } \\
\hline Emergence rate per day (plants/d) & $3.2 \mathrm{ab}$ & $7.5^{\mathrm{z}} \mathrm{a}$ & $-0.2 \mathrm{~b}$ & $1.2 \mathrm{ab}$ & 7.5 \\
\hline Emergence proportion $(\%)$ & $23^{z} \mathrm{a}$ & $23 \mathrm{a}$ & $-8 \mathrm{a}$ & $8 \mathrm{a}$ & 34 \\
\hline Early vigor (1-9 scale) & $-0.3 \mathrm{~b}$ & $1.8^{\mathrm{z}} \mathrm{a}$ & $-0.8^{\mathrm{z}} \mathrm{b}$ & $0.5 \mathrm{ab}$ & 1.4 \\
\hline
\end{tabular}

zThe estimate exceeded twice the standard error.

yMean separation within columns by Fisher's protected LSD at $P=0.05$. Means followed by the same letter, within the same column, are not significantly different.

$\mathrm{x} 1=$ the poorest value, $5=$ the average value, $9=$ the most favorable value.

(Davis et al., 1988; Revilla et al., 2000b). 'Golden Bantam' x 'Stowell's Evergreen' had more quality than the other hybrids. Only ‘Golden Bantam'x 'Stowell's Evergreen' and ‘Golden Bantam'x 'Country Gentleman' had significant heterosis for enough traits to be considered true heterotic patterns.

\section{Literature Cited}

Davis, D.W., J.L. Brewbaker, and K. Kaukis. 1988. Registration of 'NE-HY-13A' and 'NE-HY-13B' complementary cultivars of maize germplasm. Crop Sci. 28:381.

Hotchkiss, J.R., P. Revilla, and W.F. Tracy. 1997. Variation of cold tolerance among open-pollinated sweet corn cultivars. HortScience 32:719-723.

Keeratinijakal, V. and K.R. Lamkey. 1993. Response to reciprocal selection in BSSS and BSCB1 maize populations. Crop Sci. 33:73-77.

Martins, M.E.Q.P. and W.J. Da Silva. 1998. Genetic and genotypic frequencies of endosperm mutants in maize populations under natural selection. J. Hered. 89:516-524.

Ordás,A.1991. Heterosis in crosses between American and Spanish cultivars of maize. Crop. Sci. 31:931-935.

Ordás, A., P. Revilla, R.A. Malvar, and M.E. Cartea. 1994. Development of sweet corn hybrids adapted to the environmental conditions of the northwest of Spain. Maydica 39:171-175.

Revilla, P., J.R. Hotchkiss, and W.F. Tracy. 2003. Cold tolerance evaluation in a diallel among open-pollinated sweet corn cultivars. HortScience 38:88-91.

Revilla, P. and W.F. Tracy. 1997. Heterotic patterns among open-pollinated sweet corn cultivars. J. Amer. Soc. Hort. Sci. 122:319-324.

Revilla, P., R.A. Malvar. M.C.Abuín, B. Ordás, P. Soengas, and A. Ordás. 2000a. Genetic background effect on germination of sul maize and viability of the sul allele. Maydica 45:109-111.

Revilla, P., P. Velasco, M.I. Vales, R.A. Malvar, and A. Ordás. 2000b. Cultivar heterosis between sweet and Spanish corn. J. Amer. Soc. Hort. Sci. 125:684-688.

Smith, P.G. and A.H. Millet. 1964. Germinating and sprouting responses of the tomato at low temperatures. J. Amer. Soc. Hort. Sci. 84:480-484.

Tracy, W.F. 2001. Sweet corn, p. 147-187. In: A.R. Hallauer (ed.). Specialty types of maize. $2^{\text {nd }}$ ed. CRC Press, Boca Raton, Fla.

Vales, M.I., R.A. Malvar, P. Revilla, and A. Ordás. 2001. Recurrent selection for grain yield in two Spanish maize synthetic populations. Crop Sci. 41:15-19.

Velasco, P., P. Revilla, R.A. Malvar, A. Butrón, and A. Ordás. 2002. Resistance to corn borer in crosses between sweet and field corn populations. J. Amer. Soc. Hort. Sci. 127:689-692. 